\title{
中性化腹膜透析液のグルコース分解物濃度について
}

\author{
山本 忠司出雲谷 剛 奥野 仙二 山川智之 \\ 仁真会白鷺病院
}

key words：腹膜透析，中性透析液，酸性透析液，グルコース分解物

〈要旨〉

中性透析液（N-PD）のグルコース分解物（GDPs）濃度および pH を同一条件で測定し比較検討した．

対象とした N-PD は平成 14 年 8 月までに薬価収載された 4 社の製品である. これら製品の内, N-PD, 1.5\%およ び $2.5 \%$ 液に対し製造後 4 か月に GDPs 濃度を測定した. 比較として製造後 4 から 12 か月の N-PD, $4.0 \%$ およひ製 造後 12 か月の酸性透析液（A-PD）についても測定した．また，長期保存の影響をみるために製造後 1 年の GDPs 濃度も測定した. 測定項目はグルコース室側 $\mathrm{pH}$, 混合後 $\mathrm{pH}$ およびGDPs 濃度で, GDPsについては, 3-デオキシ グルコソン (3-DG), グリオキサール，メチルグリオキサール，ホルムアルデヒド，アセトアルデヒド (AcA)，5ヒドロキシメチルフルフラール(5-HMF)，フルフラール，ギ酸，およびレブリン酸とし，HPLC 法により 3 バッグ を測定した。

N-PD のグルコース室側 pH は 2.90〜6.04 であった. 混合後 pH では 6.67〜7.47であった. A-PD は 5.17〜5.25 であった. N-PD 各社の製品はギ酸とレブリン酸を除くGDPsのすべてに有意差を認めた. GDPs の総量 $(\mu \mathrm{mol} / \mathrm{L})$ は, 1.5\%で 30.4〜95.1，2.5\%で51.4〜136.5，4.0\%で78.4〜192.2 と製品間に差を認めた．また，弚の内訳は3DG と 5-HMF が平均 95\%を占めていた. N-PD の低 GDPs 化には, 3-DG と 5-HMF の低減が必要であるが, 3-DG と 5-HMF はグルコース室側 pH 4.5 付近を境に鏡像的変化をするため, $\mathrm{pH}$ による調整は困難と思われた. A-PDの GDPs 総量では $1.5 \%$ で324.9，2.5\%で 481.8，4.0\%で594.2 と N-PD に比べ約 3 倍から 10 倍高值であった。

長期保存 (1 年間) による N-PD の GDPs 濃度 $(\mu \mathrm{mol} / \mathrm{L})$ の変化では, $1.5 \%$ 液で AcA のみが平均で 1.2 から 2.8 に増加し， $2.5 \%$ 液でも AcA のみが 1.4 から 2.7 と増加した。他の GDPs には变化なく, N-PD は A-PD に比べ長 期保存でも安定していた.

各社 N-PD は pH を中性化し GDPs を低減させるということでは, 弚の目的が達成されているといえる. しかし， 製剤設計の違いから GDPs 濃度に差があることが判明した，炎の影響を考察するためには，乥れぞれの GDPs の細 胞障害性，生体適合性についてさらに検討する必要がある。

\section{Glucose degradation products in neutralized peritoneal dialysis solution}

Tadashi Yamamoto, Tsuyoshi Izumotani, Senji Okuno, Tomoyuki Yamakawa

Kidney Center, Shirasagi Hospital

Four kinds of neutralized peritoneal dialysis solutions (N-PD) with a low level of glucose degradation products (GDPs) are currently marketed. The GDP concentrations of each N-PD have been confirmed in some reports, but the methods with which the levels have been measured are not uniform. We measured the concentration of GDPs and checked the $\mathrm{pH}$ of both the glucose chamber and after mixture of the N-PDs under the same methods and conditions, and compared these with an acid peritoneal dialysis solution (A-PD). The N-PDs studied were Midpeliq $L^{\circledR}$ (Terumo), PD-solita $\cdot A^{\circledR}$ (Shimizu Medical), Perisate $\mathrm{NL}^{\circledR}$ (JMS) and Stay $\cdot$ safe balance ${ }^{\circledR}$ (Fresenius Medical Care). The concentrations of GDPs were measured 4 and 12 months after manufacture using high performance liquid chromatography (HPLC). The GDPs assayed were 3-deoxyglucosone (3-DG), glyoxal $(G \mid x)$, methylglyoxal ( $M-G \mid x)$, formaldehyde ( $F o A)$, acetaldehyde ( $A c A)$, 5-hydroxymethylfurfural (5-HMF), furfural (2-FA), formic acid and levulinic acid.

The $\mathrm{pH}$ values of the N-PDs ranged from 2.90 to 6.04 in the glucose chamber, and from 6.67 to 7.47 after

山本 忠司 仁真会白㲛病院 于546-0002 大阪市東住吉区杭全 7-11-23

Tadashi Yamamoto Tel :06-6714-1661 Fax:06-6719-6169 E-mail : yamamoto@shirasagi-hp.or.jp 〔受付：平成 16 年 4 月 8 日, 受理：平成 16 年 9 月 24 日〕 
mixture, and in A-PD ranged from 5.17 to 5.25. The total amount of GDPs $(\mu \mathrm{mol} / \mathrm{L})$ in the N-PDs ranged from 30.4 to 95.1 at $1.5 \%$, from 51.4 to 136.5 at $2.5 \%$ and from 78.4 to 192.2 at $4.0 \%$. The concentrations of $3-$ DG and 5-HMF made up an average of $95 \%$ in the total GDPs. The total amount of GDPs in the A-PD at $1.5 \%$, $2.5 \%$ and $4.0 \%$ was $324.9,481.8$ and 594.2 , respectively and they were 3 to 10 times higher than N-PD. As for the change in the concentration of GDPs at a shelf life of 12 months in N-PD, only AcA increased from 1.2 to 2.8 at $1.5 \%$, and from 1.4 to 2.7 at $2.5 \%$, and other GDPs did not change significantly. In A-PD, only AcA decreased, and Glx, FoA and 5-HMF increased. The N-PD was more stable than A-PD during long-term storage.

The N-PD achieved the goal of neutralizing the $\mathrm{pH}$ and reducing the concentration of GDPs. However, even in the same N-PD, some differences in the concentrations of GDPs could be recognized. It remains necessary to clarify the cytotoxicity of GDPs and the biocompatibility of each NP-D.

\section{緒言}

腹膜透析液の生体適合性の問題については, 以前よ り透析液 $\mathrm{pH}$ や高浸透圧が指摘されてきた ${ }^{1,2)} .1989$ 年 に Van Bronswijk ら ${ }^{3)}$ にり中性化した腹膜透析液 でも中皮細胞に傷害性のあることが報告され，これは 透析液の加熱滅菌による GDPs (glucose degradation products) に由来していることが指摘された 的な GDPs の低隇には，非加熱による滅菌を行う必要 があるが：その技術的な問題から 2 室構造と $\mathrm{pH}$ 調節 による加熱滅菌, 中性化·低 GDP 透析液の開発が行 われてきだ7,

本邦でも, 腹膜透析液の生体適合性向上の目的から, 低 GDPs 化と中性化に向けた中性化腹膜透析液（中性 透析液）が開発され，平成 12 年 7 月以来，平成 14 年 8 月までに 4 社の製品（ステイセーフバランス®：フ レゼニウス・メディカルケア・ジャパン, PD—ソリ タ・ $\mathrm{A}^{\circledR}$ : シミズメディカル，ペリセート $\mathrm{NL}^{\circledR}$ ： ジェイ・エム・エス, ミッドペリック $\mathrm{L}^{\circledR}$ ：テルモ)が 薬価収載された。これら製品はすべて基本的に 2 室構 造で混合後に中性となるよう各室が $\mathrm{pH}$ 調整され, 特 にグルコース室側を酸性にして，またグルコース室側 の容量や含有電解質も調整して GDPs 生成を抑える よう設計されている。しかし，これら中性透析液に関 しては，pH と GDPsが調整されているものの製品に よる差があることが知られている，特にGDPs 濃度に 関しては, 各社の製品試験もしくは研究論文などによ り確認することができるが，これは統一された分析法 によるものではなく，正確な比較がなされていないの が現状である。

今回, 各社製品の GDPs 濃度㐨よび $\mathrm{pH}$ を同一条件 で測定することにより，その差を明らかにし，製剤設 計による影響について言及する。

\section{I . 対象と方法}

測定対象とした 2 室中性透析液は平成 14 年 8 月ま でに薬価収載された 4 社（A〜D 社）の $1.35 \%$ から $2.50 \%$ グルコース濃度液である。これら透析液に対し， 製造後 4 か月にグルコース室側 $\mathrm{pH}$ ，混合後 $\mathrm{pH}$ 押よ びGDPs 濃度を測定した。また，参考比較として中性 透析液 3.86 加 $4.00 \%$ の製造後 4 加月の A 社, 製造 後 12 か月の B 社, 製造後 8 か月の C 社製品, および従 来型酸性透析液 $\mathrm{E}$ 社の $1.35 \%$ から $4.00 \%$ グルコース 液, 製造後 12 か月も測定した。また，長期保存による GDPs 濃度の変化をみるために, 中性透析液について は 12 か月間, 空調のない倉庫で保管され, 酸性透析液 は空調のある倉庫で保管された。各透析液のグルコー ス濃度は統一されていないが, グルコース濃度 $1.35 \%$ から $1.60 \%$ ののを $1.5 \%, 2.27 \%$ から $2.50 \%$ のの を $2.5 \% ， 3.86 \%$ から 4.00\%のものを 4.0\%とした。

測定 GDPs については，3-デオキシグルコソン (3$\mathrm{DG})$ ，グリオキサール (Glx)，メチルグリオキサール (M-Glx), ホルムアルデヒド ( $\mathrm{FoA})$, アセトアルデヒ ド (AcA)，5-ヒドロキシメチルフルフラール (5$\mathrm{HMF})$ ，フルフラール (2-FA)，ギ酸，およびレブリ ン酸とし， 3 バッグを測定した。

測定は以下に述べる HPLC 法により行った。試薬に ついては, 3-DG 注同仁化学製, M-Glx は SIGMA 製, AcA は MERCK 製，5-HMF は Aldrich 製，Glx， FoA，2-FA，ギ酸，およびレブリン酸は関東化学製を 標品として用いた。 その他の試薬は, 関東化学製また は和光純薬製を用いた。

1. 3-DG, Glx, M-Glx

試料 $3 \mathrm{~mL}$ に $0.4 \%$ エニレンジアミンを $2 \mathrm{~mL}$ 加 えて室温で 4 時間放置した後, HPLC 測定した。標準 溶液をそれぞれの標品から同様に調製し，1点検量線 によりそれぞれの濃度を求めた。

カラムは Inertsil ODS-3 V（ジーエルサイエンス, 
$4.6 \mathrm{~mm} \phi \times 250 \mathrm{~mm}$ ) を使用し， カラム温度室温，UV 検出波長 $312 \mathrm{~nm}$, 流速 $1 \mathrm{~mL} / \mathrm{min}$, 移動相は, $\mathrm{A}$ ：水/ アセトニトリル $=8 / 2, \mathrm{~B}:$ 水 $/$ アトニトリル $=7 / 3$ と し，移動相 B を 15 分まで $0 \%$ ，15 分から 20 分にかけ て 100\%，30 分から 31 分にかけて 0\%とするグラジェ ント条件で分析した.

\section{FoA, AcA}

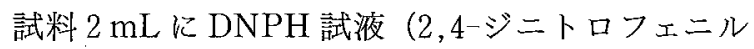
ヒドラジン $0.15 \%$, 硫酸 $5 \%$ ，アセトニトリル $50 \%$ を 含有) $1 \mathrm{~mL}$ を加えて室温で 1 時間放置した後, HPLC 測定した，標準溶液は，それぞれの標品から 3 種類の 濃度を同様に調製し，3点検量線の一次回帰式よりそ れぞれの濃度を求めた。

カラムは STR ODS-M（島津テクノリサーチ, 4.6 $\mathrm{mm} \phi \times 250 \mathrm{~mm})$ を使用し, カラム温度 $40^{\circ} \mathrm{C}$, UV 検 出波長 $365 \mathrm{~nm}$, 移動相は, $\mathrm{A}$ ：水/テトラヒドロフラ ン=8/2, B：アセトニトリルとし, 流速 $1 \mathrm{~mL} / \mathrm{min}$, 移動相 B を $30 \%$ から 15 分で50\%，15 分から 20 分に かけて $100 \%$ ，23 分から 25 分にかけて $30 \%$ とるグ ラジェント条件で分析した。

\section{5-HMF, 2-FA}

試料をそのまま, HPLC 測定した。標準溶液はそれ ぞれの標品から調製し，1点検量線によりそれぞれの 濃度を求めた。

カラムは ULTORON PS-80 H (信和化工, $8 \mathrm{~mm} \phi$ $\times 300 \mathrm{~mm}$ ) を使用し, カラム温度 $60^{\circ} \mathrm{C}$, UV 検出波長 $284 \mathrm{~nm}$, 過塩素酸で pH 2.1 に調製した水を移動相と して分析した。

\section{4. ギ酸, レブリン酸}

試料をそのまま, HPLC 測定した，標準溶液は，そ れぞれの標品から 3 濃度を調製し，3点検量線の一次 回帰式よりそれぞれの濃度を求めた。

カラムは ULTORON PS- $80 \mathrm{H}$ (信和化工, $8 \mathrm{~mm} \phi$ $\times 300 \mathrm{~mm}$ ) 使用し, カラム温度 $60^{\circ} \mathrm{C}, \mathrm{UV}$ 検出波長 $210 \mathrm{~nm}$, 過塩素酸で $\mathrm{pH} 2.1$ に調製した水を移動相と して分析した。

これらの測定法による誤差については，同一の標準 溶液を連続して 6 回分析したときの併行精度は, 3-DG は2.16〜138.49 $\mu \mathrm{M}$ の範囲で 0.07〜0.77\%，Glxは $0.63 \sim 20.10 \mu \mathrm{M}$ の範囲で 0.29〜1.04\%, M-Glx は $0.64 \sim 10.26 \mu \mathrm{M}$ の範囲で 0.43〜2.90\%, FoA は $2.50 \sim 79.92 \mu \mathrm{M}$ の範囲で $0.19 \sim 1.37 \%$, AcA は $2.58 \sim 165.38 \mu \mathrm{M}$ の範囲で $0.21 〜 1.53 \%, 5-\mathrm{HMF}$ は $0.67 \sim 43.08 \mu \mathrm{M}$ の範囲で $0.16 〜 2.43 \%, 2-\mathrm{FA}$ は $0.36 \sim 23.14 \mu \mathrm{M}$ の範囲で 0.26〜 5.19\%であった.

統計学検討は two sample $t$ test を用い, $\mathrm{p}<0.05$ を
有意とした，測定結果は平均士 $\mathrm{SD}(\mu \mathrm{mol} / \mathrm{L})$ で示し た。

\section{II. 結 果}

製造後 4 か月の $1.5 \%$ およ゙ $2.5 \%$ 中性透析液お よび製造後 12 か月の酸性透析液のグルコース室側 $\mathrm{pH}$, 混合後 $\mathrm{pH}, \mathrm{GDPs}$ 濃度を表 1,2 に示す。 中性透 析液の GDPs 総量比較を図 1 に示す。中性透析液グル コース室側 $\mathrm{pH}$ は 2.92〜6.04 と大きな差を認め, 最も 低值は C 社 $1.5 \%$ の 2.92, 最も高值は $\mathrm{A}$ 社 $2.5 \%$ の 6.04 であった，混合後 $\mathrm{pH}$ では最も低值は A 社 $2.5 \%$ の 6.67 , 最も高值は B 社 $2.5 \%$ の 7.47 であった. 酸性 透析液では, 5.17 から 5.25 であった。

GDPs 濃度 $(\mu \mathrm{mol} / \mathrm{L})$ では中性透析液 1.5\%で, AcA は $\mathrm{A}, \mathrm{C}$ 社が $\mathrm{B}, \mathrm{D}$ 社より高值を示し $(\mathrm{p}<0.0001)$, $\mathrm{A}$ 社とC社の間にも有意差が認められた $(\mathrm{p}=$ 0.0132). FoA は A 社が B , C , D 社より高值を示した $(\mathrm{p}<0.0001)$. M-Glx は A 社にのみ検出された. Glx は $D$ 社が $A$ 社 $(p=0.0029), B$ 社 $(p=0.0012), C$ 社 $(\mathrm{p}=0.0101)$ より高值であった. $3-\mathrm{DG}$ は $\mathrm{A}$ 社が $\mathrm{B}$, $\mathrm{C}, \mathrm{D}$ 社より高值を示した $(\mathrm{p}<0.0001)$. 5-HMF は C, $\mathrm{D}$ 社が $\mathrm{A} ， \mathrm{~B}$ 社より高值を示し $(\mathrm{p}<0.0001), \mathrm{C}$ 社と $\mathrm{D}$ 社の間にも有意差が認められた $(\mathrm{p}=0.0013)$ 。2-FA は C, D 社に検出されたが,この 2 社の間に有意差はな かった. ギ酸およびレブリン酸はすべてで検出限界以 下であった。酸性透析液 (E 社) は製造後 12 か月の值 であるが，5-HMF は C 社 $(\mathrm{p}=0.0098)$ と D 社 $(\mathrm{p}=$ 0.0445）より低値を示し，A，B社より高値であった $(\mathrm{p}<0.0001)$ ．他の GDPs では中性透析液の 6 倍から 110 倍程度高值を示した $(\mathrm{p}<0.0001)$ 。また, ギ酸が高 濃度で検出された。 GDPs の総量 $(\mu \mathrm{mol} / \mathrm{L})$ としては, $\mathrm{A}$ 社が $95.0 \pm 3.4, \mathrm{~B}$ 社が $30.5 \pm 2.3, \mathrm{C}$ 社が $36.3 \pm$ $0.1, \mathrm{D}$ 社が $45.3 \pm 0.2$ ですべての製品間に有意差を認 めた $(\mathrm{p}<0.0001)$. 総量の内, 3-DG と 5-HMF の合計 の占める割合は, $\mathrm{A}$ 社が $95.8 \%, \mathrm{~B}$ 社が $93.1 \%, \mathrm{C}$ 社 が $92.3 \%$, D 社が $95.8 \%$,さらに 3-DG と 5-HMF の 内，3-DGの占める割合は， A 社が $98.5 \%, \mathrm{~B}$ 社が $97.5 \%, \mathrm{C}$ 社が $75.2 \% ， \mathrm{D}$ 社が $82.8 \%$ であった。

中性透析液 2.5\%で, AcA は A, C 社が B 社（p= $0.0013)$ と $\mathrm{D}$ 社 $(\mathrm{p}=0.0015)$ より高值を示し， $\mathrm{A}$ 社と $\mathrm{C}$ 社の間には有意差はなかった。 FoA は A 社が B 社 $(p=0.0006), C$ 社 $(p=0.0001)$ と $D$ 社 $(p=0.0002)$ より高值を示した: M-Glx は $\mathrm{A}$ 社にのみ検出された. GIx は D 社が $A$ 社 $(p=0.0005), B$ 社 $(p<0.0001)$ ， $\mathrm{C}$ 社 $(\mathrm{p}<0.0001)$ より高值であった。 $3-\mathrm{DG}$ は $\mathrm{A}$ 社が 
表 1 Concentration of GDPs and $\mathrm{pH}$ of each peritoneal dialysis solution (1.5\% glucose concentration)

\begin{tabular}{lccccc}
\hline & $\mathrm{A}$ & $\mathrm{B}$ & $\mathrm{C}$ & $\mathrm{D}$ & $\mathrm{E}$ \\
\hline $\mathrm{pH}$ (glucose side) & $5.98 \sim 6.04$ & $4.67 \sim 4.68$ & $2.92 \sim 2.96$ & $3.81 \sim 3.89$ & - \\
pH (after mixture) & $6.73 \sim 6.77$ & $7.35 \sim 7.43$ & $7.19 \sim 7.31$ & $7.35 \sim 7.40$ & $5.23 \sim 5.25$ \\
Acetaldehyde & $1.5 \pm 0.1^{\mathrm{a}}$ & $0.7 \pm 0.1$ & $1.7 \pm 0.1^{\mathrm{a}}$ & $0.7 \pm 0.1$ & $77.1 \pm 5.0$ \\
Formaldehyde & $1.8 \pm 0.1^{\mathrm{b}}$ & $1.2 \pm 0.1$ & $0.8 \pm 0.1$ & $0.7 \pm 0.1$ & $4.3 \pm 0.2$ \\
Methylglyoxal & $0.51 \pm 0.01$ & $<0.04$ & $<0.04$ & $<0.04$ & $3.50 \pm 0.40$ \\
Glyoxal & $0.17 \pm 0.01$ & $0.13 \pm 0.01$ & $0.16 \pm 0.01$ & $0.31 \pm 0.04^{\mathrm{c}}$ & $2.36 \pm 0.10$ \\
3-DG & $89.7 \pm 3.3^{\mathrm{b}}$ & $27.7 \pm 2.5$ & $25.2 \pm 0.1$ & $35.7 \pm 0.01$ & $206.1 \pm 11.6$ \\
5-HMF & $1.4 \pm 0.1$ & $0.7 \pm 0.1$ & $8.3 \pm 0.1^{\mathrm{d}}$ & $7.7 \pm 0.1^{\mathrm{d}}$ & $6.7 \pm 0.6$ \\
Furfural & $<0.04$ & $<0.04$ & $0.11 \pm 0.01$ & $0.08 \pm 0.01$ & $0.69 \pm 0.10$ \\
Formic acid & $<20$ & $<20$ & $<20$ & $<20$ & $24.1 \pm 1.2$ \\
Levulinic acid & $<10$ & $<10$ & $<10$ & $<10$ & $<10$ \\
Total GDPs & $95.0 \pm 3.4^{\mathrm{e}}$ & $30.5 \pm 2.3^{\mathrm{e}}$ & $36.3 \pm 0.1^{\mathrm{e}}$ & $45.3 \pm 0.2^{\mathrm{e}}$ & $324.9 \pm 13.1$
\end{tabular}

GDPs and $\mathrm{pH}$ in neutralized solution (A-D) were measured 4 months after manufacture, and 12 months in acid solution (E). Data were expressed as mean $\mathrm{SD}\left(\mu \mathrm{mol} / \mathrm{L}\right.$ ), $\mathrm{N}=3 .{ }^{\mathrm{a}} \mathrm{p}<0.0001$ (vs. $\mathrm{B}$ and $\mathrm{D}$ ), ${ }^{\mathrm{b}} \mathrm{p}<0.0001$ (vs. $\mathrm{B}$, $\mathrm{C}$ and D), ${ }^{\mathrm{c}} \mathrm{p}<0.01$ (vs. A, B and C), ${ }^{d} \mathrm{p}<0.0001$ (vs. A and B), ${ }^{e} \mathrm{p}<0.0001$ for each other.

表 2 Concentration of GDPs and $\mathrm{pH}$ of each peritoneal dialysis solution (2.5\% glucose concentration)

\begin{tabular}{lccccc}
\hline & $\mathrm{A}$ & $\mathrm{B}$ & $\mathrm{C}$ & $\mathrm{D}$ & $\mathrm{E}$ \\
\hline $\mathrm{pH}$ (glucose side) & $6.00 \sim 6.04$ & $4.60 \sim 4.67$ & $2.93 \sim 2.94$ & $3.84 \sim 3.85$ & - \\
$\mathrm{pH}$ (after mixture) & $6.67 \sim 6.78$ & $7.34 \sim 7.47$ & $7.15 \sim 7.23$ & $7.30 \sim 7.39$ & $5.17 \sim 5.18$ \\
Acetaldehyde & $1.9 \pm 0.1^{\mathrm{a}}$ & $0.8 \pm 0.1$ & $1.9 \pm 0.1^{\mathrm{a}}$ & $1.0 \pm 0.1$ & $120.5 \pm 7.8$ \\
Formaldehyde & $1.9 \pm 0.1^{\mathrm{b}}$ & $1.2 \pm 0.1$ & $0.4 \pm 0.1$ & $0.5 \pm 0.1$ & $3.7 \pm 0.2$ \\
Methylglyoxal & $0.61 \pm 0.01$ & $<0.04$ & $<0.04$ & $<0.04$ & $4.50 \pm 0.80$ \\
Glyoxal & $0.35 \pm 0.01$ & $0.20 \pm 0.01$ & $0.27 \pm 0.01$ & $0.49 \pm 0.02^{\mathrm{c}}$ & $3.56 \pm 0.13$ \\
3-DG & $130.1 \pm 2.5^{\mathrm{b}}$ & $47.6 \pm 1.4$ & $43.4 \pm 1.0$ & $50.8 \pm 0.8$ & $307.1 \pm 10.3$ \\
5-HMF & $1.6 \pm 0.1$ & $1.6 \pm 0.1$ & $14.7 \pm 0.6^{\mathrm{d}}$ & $11.8 \pm 0.3^{\mathrm{d}}$ & $11.3 \pm 1.2$ \\
Furfural & $<0.04$ & $<0.04$ & $0.18 \pm 0.01$ & $0.13 \pm 0.01$ & $1.25 \pm 0.10$ \\
Formic acid & $<20$ & $<20$ & $<20$ & $<20$ & $30.0 \pm 3.5$ \\
Levulinic acid & $<10$ & $<10$ & $<10$ & $<10$ & $<10$ \\
Total GDPs & $136.5 \pm 2.5^{\mathrm{e}}$ & $51.5 \pm 1.6^{\mathrm{e}}$ & $60.9 \pm 1.8^{\mathrm{e}}$ & $64.7 \pm 1.4^{\mathrm{e}}$ & $481.8 \pm 23.8$
\end{tabular}

GDPs and $\mathrm{pH}$ in neutralized solution (A-D) were measured 4 months after manufacture, and 12 months in acid solution (E). Data were expressed as mean $\pm \mathrm{SD}(\mu \mathrm{mol} / \mathrm{L}), N=3 .{ }^{a} \mathrm{p}<0.002$ (vs. B and D), ${ }^{b} \mathrm{p}<0.001$ (vs. B, $\mathrm{C}$ and $\mathrm{D}),{ }^{\mathrm{c}} \mathrm{p}<0.01$ (vs. A, B and C), ${ }^{\mathrm{d}} \mathrm{p}<0.0001$ (vs. A and $\mathrm{B}$ ), ${ }^{\mathrm{e}} \mathrm{p}<0.0001$ for each other.

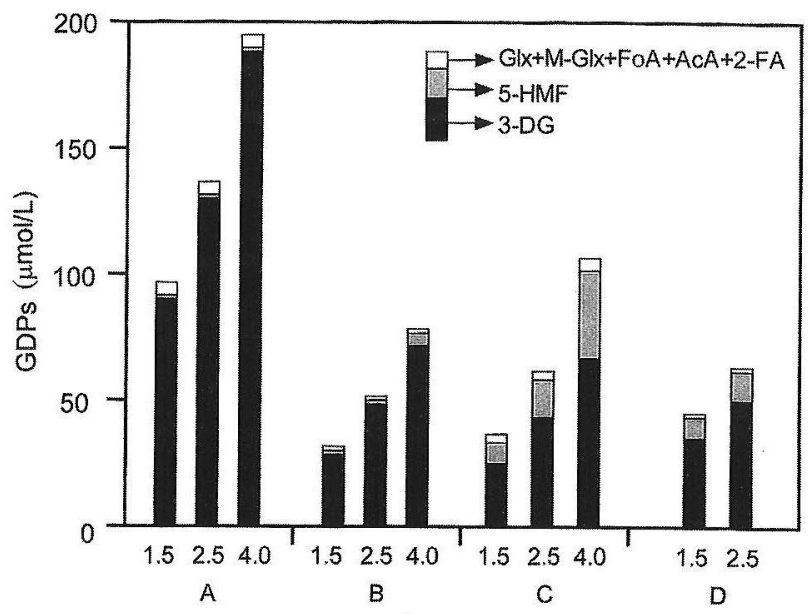

図 1 Comparison of total GDPs concentration in $1.5 \%, 2.5 \%$ and $4.0 \%$ solutions among four products. Data are mean \pm $\mathrm{SD}, \mathrm{N}=3$.
B，C，D社より高值を示した $(\mathrm{p}<0.0001)$ ，5-HMF は C, D 社が A, B 社より高值を示し $(\mathrm{p}<0.0001)$, $\mathrm{C}$ 社とD社の間にも有意差が認められた $(\mathrm{p}=$ 0.0015).2-FA \& $C$ 社と $D$ 社に検出され，この 2 社の 間にも有意差が認められた（ $\mathrm{p}=0.0161 ）$ 。ギ酸および レブリン酸はすべてで検出限界以下であった。酸性透 析液は製造後 12 か月の值ではあるが, 5-HMF は A, $\mathrm{B}$ 社より高值を示し $(\mathrm{p}<0.0001), \mathrm{D}$ 社とは差を認め ず, C 社より低值を示した $(\mathrm{p}=0.0105)$. 他の GDPs で は中性透析液より 7 倍から 150 倍程度高值を示し $(\mathrm{p}<0.0001)$ ，特にギ酸が高濃度で検出された. GDPS の総量 $(\mu \mathrm{mol} / \mathrm{L})$ では, $\mathrm{A}$ 社が $136.5 \pm 2.5, \mathrm{~B}$ 社が $51.4 \pm 1.6, \mathrm{C}$ 社が $60.9 \pm 1.8, \mathrm{D}$ 社が $64.7 \pm 1.4$ です べての製品間で有意差を認めた（ $p<0.0001 ）$. 総量の 内, 3-DG と 5-HMF の占める割合は, A 社が $96.5 \%$ ， B 社が $95.5 \%, \mathrm{C}$ 社が $95.4 \%, \mathrm{D}$ 社が $96.8 \%$ でさ 
表 3 Concentration of GDPs and $\mathrm{pH}$ of each peritoneal dialysis solution $4.0 \%$ glucose concentration)

\begin{tabular}{lcccc}
\hline & $\mathrm{A}$ & $\mathrm{B}$ & $\mathrm{C}$ & $\mathrm{E}$ \\
\hline $\mathrm{pH}$ (glucose side) & $5.86 \sim 5.97$ & $4.54 \sim 4.58$ & $2.90 \sim 2.93$ & - \\
$\mathrm{pH}$ (after mixture) & $6.65 \sim 6.70$ & $7.11 \sim 7.17$ & $7.22 \sim 7.28$ & $5.18 \sim 5.21$ \\
Acetaldehyde & $1.6 \pm 0.1$ & $0.4 \pm 0.1$ & $2.9 \pm 0.1$ & $116.0 \pm 2.4$ \\
Formaldehyde & $1.7 \pm 0.1$ & $1.0 \pm 0.1$ & $1.4 \pm 0.1$ & $3.7 \pm 0.2$ \\
Methylglyoxal & $0.61 \pm 0.01$ & $<0.04$ & $0.09 \pm 0.01$ & $5.23 \pm 0.60$ \\
Glyoxal & $0.41 \pm 0.01$ & $0.31 \pm 0.02$ & $0.66 \pm 0.01$ & $3.41 \pm 0.17$ \\
3-DG & $186.2 \pm 3.1$ & $71.5 \pm 0.8$ & $65.3 \pm 1.4$ & $421.4 \pm 24.9$ \\
5-HMF & $1.7 \pm 0.1$ & $5.1 \pm 0.1$ & $36.0 \pm 1.0$ & $13.1 \pm 1.3$ \\
Furfural & $<0.04$ & $0.06 \pm 0.01$ & $0.51 \pm 0.01$ & $1.37 \pm 0.10$ \\
Formic acid & $<20$ & $<20$ & $<20$ & $26.5 \pm 1.4$ \\
Levulinic acid & $<10$ & $<10$ & $<10$ & $<10$ \\
Total GDPs & $192.3 \pm 2.9$ & $78.3 \pm 1.0$ & $106.8 \pm 2.5$ & $594.2 \pm 21.4$ \\
\hline
\end{tabular}

GDPs and $\mathrm{pH}$ of $\mathrm{A}, \mathrm{B}, \mathrm{C}$ and $\mathrm{E}$ solutions were measured 4, 12, 8 and 12 months after manufacture, respectively. Data were expressed as mean $\pm \mathrm{SD}(\mu \mathrm{mol} / \mathrm{L}), \mathrm{N}=3$.

に 3-DG と 5-HMF の内, 3-DG の占める割合は, A 社 が $98.8 \%, \mathrm{~B}$ 社が $96.7 \%, \mathrm{C}$ 社が $74.7 \%, \mathrm{D}$ 社が $81: 2 \%$ であった。

製造後 4 から 12 か月後の中性透析液 $4.0 \%$ および 酸性透析液 $4.0 \%$ のグルコース室側 $\mathrm{pH}$, 混合後 $\mathrm{pH}$, GDPs 濃度を表 3 に示す，中性透析液の GDPs 総量比 較を図 1 に示す。製造後の期間が相違するため単純に 比較はできないが, 中性透析液で Glx, 3-DG, 5- HMF は $1.5 \%, 2.5 \%$ 液より高值を示した $(\mathrm{p}<0.0001) . \mathrm{pH}$, GDPs 濃度分布は $1.5 \% ， 2.5 \%$ 中性透析液と同様の傾 向を示したが，5-HMF の占める割合は増加する傾向 にあった，総量に执いても 1.5\%，2.5\%中性透析液よ り高值を示した。

長期保存 ( 1 年間) による中性透析液の GDPs 濃度の 変化では，1.5\%液でAcA が平均で $1.2 \pm 0.5$ から $2.8 \pm 0.6$ に增加 $(\mathrm{p}=0.0022), 2.5 \%$ 液でも AcA で $1.4 \pm 0.6$ から $2.7 \pm 0.9$ と増加（ $\mathrm{p}=0.0148 ）$ したが, その他の GDPs には有意な変化は認めなかった。酸性

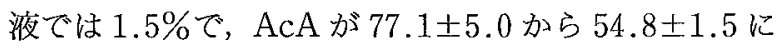
低下（p=0.0216），G1x が $2.4 \pm 0.1$ から $4.0 \pm 0.1$ に 増加 $(p=0.0007), 5-H M F$ も $6.7 \pm 0.6$ から $9.7 \pm 0.4$ に増加( $\mathrm{p}=0.0059)$ した. 2.5\%では, AcA が 120.1士 7.8 から $82.3 \pm 3.0$ に低下 $(\mathrm{p}=0.0233)$, FoA が $3.7 \pm$ 0.4 から $5.8 \pm 0.5$ に増加 (0.0431)，Glx が $3.6 \pm 0.1$ から $6.0 \pm 0.1$ に増加 $(\mathrm{p}<0.0001), 5-\mathrm{HMF}$ も $11.3 \pm$ 1.2 から $18.6 \pm 2.0$ に増加（ $\mathrm{p}=0.0475 ）$ した。

\section{III. 考 察}

腹膜透析液におけるグルコースの分解については, dehydration による還元酸やフラン化合物 (3-DG，5-
$\mathrm{HMF} ， 2-\mathrm{FA}$ など）の分解と， fragmentation による ケトン類やアルデヒド類 (Glx, FoA, M-Glx, AcA な ど)への分解があり,この二つの反応系は $\mathrm{pH}$ と滅菌条 件 (温度, 時間) に依存的である ${ }^{9,10)}$. 特に $\mathrm{pH}$ につい ては, dehydration は低 $\mathrm{pH} て ゙$, fragmentation は高 $\mathrm{pH}$ で促進されるとされ11 14), dehydration と fragmentationの反応を同時に抑制することは困難とされ ている（図 2)。2 室構造中性透析液では，グルコース 室側の $\mathrm{pH}(\mathrm{G}$ 室 $\mathrm{pH})$ でこれらの反応が調節される.

実際に, $\mathrm{C}$ 社と $\mathrm{D}$ 社は $\mathrm{G}$ 室 $\mathrm{pH}$ を 2.92 から 3.89 に調 節して fragmentationによる分解を抑制する方法が とられ，A 社は $\mathrm{G}$ 室 $\mathrm{pH}$ を 5.98 から 6.04 に調節し， dehydrationによる分解を㧕制する方法がとられてい る。また B 社は， 4.60 から 4.68 と中間型で調節され ている.今回測定された GDPsでも，C社とD社では， $5-\mathrm{HMF}$ 濃度は $\mathrm{A}$ 社 $\mathrm{B}$ 社よりも高值を示し, $\mathrm{A}$ 社では アルデヒド類の上昇がみられ，これら分解系による反 応が進んでいることが示された，酸性透析液では，そ の $\mathrm{pH}$ は $5.2 \sim 5.3$ 付近に調節されており， A 社と B 社の中間の值である. $\mathrm{pH}$ のみを問題にするならば, 酸 性透析液で GDPs 濃度が中性透析液より高值を示す ことは矛盾するが，これは加熱滅菌時にブドウ糖と電 解質（特に $\mathrm{NaCl}$ ), 有機酸が共存していることが理由 とされている5,15,16). 中性透析液では 2 室構造でこれら 共存イオンと乳酸をわけることにより低 GDPs 化が 図られている。

今回の分析結果では，総 GDPs 濃度の内，3-DG と 5-HMF の占める割合は $92.3 \%$ から $96.8 \%$ と大部分 であり,さらに 3-DGと 5-HMF の内, 5-HMF の占め る割合は， A 社と B 社が $1.2 \%$ から $3.3 \%$ 低值で あったが，C社と D 社は $17.7 \%$ から $25.3 \%$ と高值で 


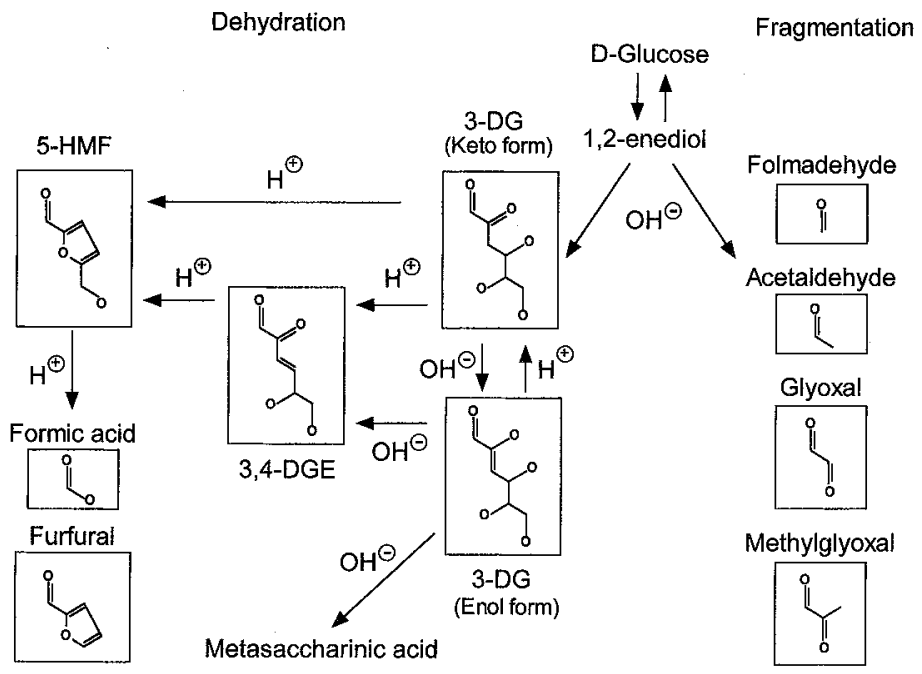

図 2 Glucose degradation, scheme for weak or strong acidic condition $\left(\mathrm{H}^{\oplus}\right)$ and weak acidic or alkaline condition $\left(\mathrm{OH}^{\ominus}\right)$ in peritoneal dialysis solution. Dehydration reaction occurs under both acidic and alkaline conditions and fragmentation reaction does under alkaline condition.

あった。つまり, 中性透析液の低 GDPs 化にはこの 3DG と 5-HMF の濃度を下げることが重要となる．3DGと 5-HMF 生成はともに図2に示すように dehydration 下での反応で複雑に関連している。グル コースは dehydration により 1,2-enediol 加ら 3-DG を生成し，この反応は弱酸性からアルカリ条件の幅広 い範囲で促進される。しかし, 3-DG から 5-HMFへの 生成は弱酸性から強酸性下で促進され，3-DG と 5HMF の生成をともに抑制することは困難となる。ま た，水素イオン濃度による 3-DG の keto 型と enol 型 への cis-trans 構造変化も影響している. 3-DG は酸性 下およびアルカリ下で keto 型もしくは enol 型の異性 体を形成しており, 酸性下では keto 型 3-DG が形成 される傾向にあり，これは直ちに 5-HMFに変化す る.アルカリ下では enol 型が形成されるものの他の GDPs への生成経路は限られており，アルカリ下では enol 型 3-DG が蓄積傾向となることが推測される99. 実際に今回測定した各製品の $\mathrm{G}$ 室 $\mathrm{pH}$ で比較すると, 3-DG と 5-HMF の濃度の変化は, $\mathrm{pH} 4.5$ 付近を境に 鏡像的な変化をして预り (図 3), pH 4.5 以下ではグル コースから 3-DG の生成が抑制され，逆に 5-HMF の 生成が杂進していることを示している，この結果から は，5-HMF の生成を抑制する $\mathrm{G}$ 室の至適 $\mathrm{pH}$ は 4.5 付近であるといえる. 今回の研究では, $\mathrm{A}$ 社は 3-DG 生成型, $\mathrm{C}$ 社と $\mathrm{D}$ 社は $5-\mathrm{HMF}$ 生成型であり, $\mathrm{B}$ 社の $\mathrm{G}$ 室 $\mathrm{pH}$ は 4.60 から 4.68 という結果で, 最も理想的 といえた(図 3).しかし，この製品の本来の規格は 3.9 から 4.4 であり今回の $\mathrm{pH}$ は偶然であつた可能性が強
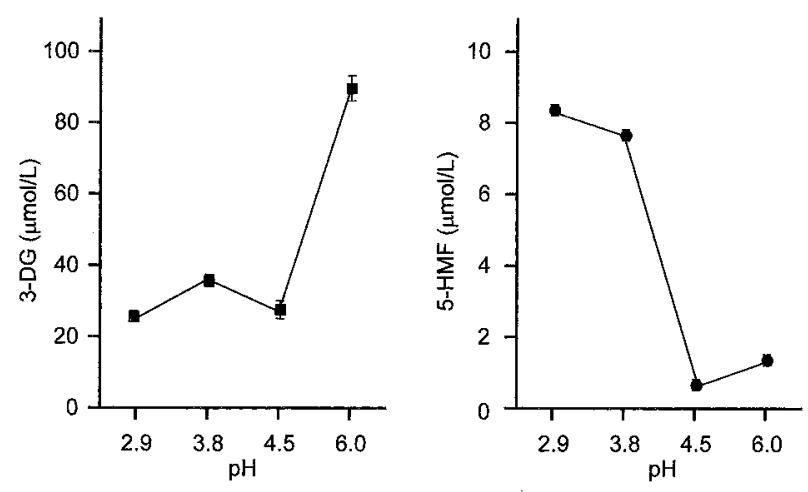

図 3 Changes of 3-DG and 5-HMF concentration in $1.5 \%$ solution with $\mathrm{pH}$ in glucose chamber. The $\mathrm{pH}$ of $2.9,3.8,4.6$ and 6.0 are product $\mathrm{C}, \mathrm{D}, \mathrm{B}$ and $\mathrm{A}$, respectively. Data are mean $\pm \mathrm{SD}, \mathrm{N}=3$.

い.また,このことは製造上， $\mathrm{G}$ 室 $\mathrm{pH}$ の厳密な調整は 困難であることも示している.

3-DG と 5-HMF のどちらの生成を抑制するかは, 3-DG と 5-HMF の toxicityにより判断されなければ ならない. 3-DG に関しては AGE形成に抢ける重要な 物質となっているが17)，生体内ではアルデヒド還元酵 素である 3-DG reductase によって速やかに，3-deoxyfructose に転換され無毒化されることが知られてい る ${ }^{18-20)}$. 実際に CAPD 患者では, 3-DG が常時負荷さ れているにもかかわらず, HD 患者と比べて血中 AGE 濃度には差がないことが報告されている ${ }^{21}$. 3-DGな ぞのアルデヒド類に関しては生体は防御システムを もって抢り, 実際の toxicity に関しては不明な部分が 多い. 5-HMF に関しては, ブドウ糖注射液の混在物を 
調べる純度試験の主要マーカーであり, 日本薬局方通 則で規定されている。 5-HMF は加熱滅菌時の温度と 時間に比例して増加することが判っており，加熱によ る変化の目安として設けられている. UV 吸光度によ る純度試験では，波長 $284 \mathrm{~nm}$ で吸光度 0.80 以下と規 定されて扔り，品質管理の基準として用いられている 指標である22). 5-HMF は in vitro の研究でアルデヒ ド類に比べ toxicity は少ないとされており 秀23 25)，ま た Wieslander ら ${ }^{8)}$ は，5-HMF が高值であることはそ れ以下のより toxicity の高いギ酸やレブリン酸に分 解されないためであり問題ないとしている，実際にグ ルコースの分解の初期段階では 5-HMF が生成され, ギ酸，レブリン酸への分解も進行するが，後期段階で は 5-HMF の分解は抑制され, 5-HMF が蓄積すると される ${ }^{26)}$. 今回の測定結果でも， C 社と $\mathrm{D}$ 社では酸性 透析液よりも高濃度の 5-HMF が検出されていたが, ギ酸およびレブリン酸はすべての中性透析液において 検出感度以下であり, 中性透析液では 5-HMF で分解 が抑制されているものと推測された。酸性透析液では, この分解は抑制されておらず，高濃度のギ酸を検出し ている.また, 5-HMF は 3-DG と比較してその濃度は $1 / 10$ 程度であることから，濃度的にもその toxicity は 低いことが推測されるが，5-HMF の前駆物質である 不飽和炭素類は低濃度でも強い toxicityをもつとさ れて抢り ${ }^{27,28)}$, 中性透析液における $\mathrm{pH}$ 調整について は 3-DG と 5-HMF の toxicity 掠よび分解系につい てのさらなる研究が必要であると思われる。

透析液に扔ける GDPsの分解については, $\mathrm{pH}$ 以外 に滅菌時の加熱温度, 加熱時間も影響する. 加熱滅菌 時に斿ける熱量と滅菌効果の関係は， $\mathrm{F}_{0}$ 值というパラ メータで示され,一般的には $121^{\circ} \mathrm{C}, 20$ 分で $\mathrm{F}_{0}$ 值は 20 という值をとる， $F_{0}$ 值は加熱時間と直線的増加関係, 加熱温度と指数的増加関係をとるが, 同じ $\mathrm{F}_{0}$ 值であれ ば, 加熱時間が短いほど GDPs の生成量は少ないとさ れ, 加熱温度 $10^{\circ} \mathrm{C}$ 上昇毎に，加熱時間は $90 \%$ 少なくす ることができる ${ }^{16,29)}$.このことから, バッグ滅菌は高温 度, 短時間で行われるべきであるが, バッグは大容量 であり，またバッグ素材の熱伝導，熱抵抗により制限 がかかり，一定した熱負荷をかけることは困難とされ る.この滅菌条件に関しては各社製造上の非公開事項 となっており明らかにされていないのが現状である。 今回の測定では, この滅菌条件による比較を行うこと ができなかったが，今後，可能であればこの問題につ いても明らかにしたいと考えている.

長期保存による影響では, 中性透析液は空調のない 倉庫で 1 年間保管され, 環境温度は $-1^{\circ} \mathrm{C}$ から $36^{\circ} \mathrm{C}$ ま
で変化し，実際の施設が経験する最悪の条件と近いも のが再現された。酸性透析液は日本薬局方に招ける基 準の室温 $\left(1^{\circ} \mathrm{C}\right.$ から $\left.30^{\circ} \mathrm{C}\right)$ で保管された。酸性透析液に おりる長期保存については, 保存温度が高いほど

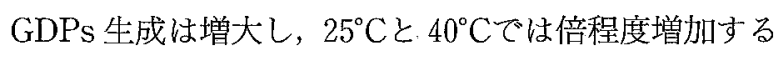
とされている ${ }^{29}$. 中性透析液 1.5\%, 2.5\%では AcA の みが平均で 2.1 倍増加し, 他の GDPs には有意な変化 はなかった，増加量についても，1２ $\mu \mathrm{mol} / \mathrm{L}$ 程度の わずかな増加であり, 長期保存による GDPs の変化に ついては過酷な条件下でも大きな影響はなく，中性透 析液は長期保存での安定性にも優れていることが示さ れた。酸性透析液は AcA が平均 0.7 倍低下, Glx, FoA, 5-HMF 注平均 1.7 倍増加し, 酸性透析液の長期 保存では中性透析液ほごの安定性が得られない傾向に あった.この AcA の低下については, 他の GDPs へ再 合成などが推測されるが詳細は不明である ${ }^{14)}$.また, 以 上の事実は, 腹膜透析液に晾学 GDPs, 特に AcA 濃 度を比較する場合には，製造後期間が統一されている 必要性を示唆したものであり, 測定には注意が必要で ある. 今回の研究では, 中性透析液の $1.5 \%$ 扝よび $2.5 \%$ 液については製造後期間を統一することができ たが, $4.0 \%$ 液については，その需要の問題から製造が 計画的に行われていないため, また, 酸性透析液につ いても製造時期の問題のため, 製造後期間を統一する ことができなかった。このようなことから今回の測定 デー夕は, 最も使用頻度の高い中性透析液 $1.5 \%$ 挍よ び $2.5 \%$ 液が中心となった。

現在, 発売されている中性透析液は $\mathrm{pH}$ を中性化し, GDPs を低隇させるということではその目的が達成さ れているといえる。しかし，加熱滅菌法を使用するか ぎり，中性透析液といえどもすべての GDPs 種を低滅 させることは不可能である. 今回測定した 4 社の GDPs 濃度の差は製造設計の差によるものであるが, 製造設計には実際の使用にお打安安全性も考慮されて おり，特に $\mathrm{A}$ 社は混合ミスがあっても極端な低 $\mathrm{pH}$ 液 が腹腔内に注入されないよう工夫されている。また， GDPs の toxicity の問題に関しては多くの in vitro の 研究がなされているが30), その標的細胞や条件等によ る差, また GDP のコンビネーションによる問題25)な どがあり，明らかにはなっていないのが現状である。 実際の臨床的有用性についてもその評価方法, 基準が 明らかではなく, 最終的には長期使用による結果を待 たねばならないと考元る。 


\section{結 語}

中性透析液の GDPs 濃度は酸性透析液の 3 分の 1 から 10 分の 1 と低值を示したが, 製剤設計の違いから 製品により差が認められた。 総 GDPs 濃度の $92 \%$ 以上 は 3-DG と 5-HMFであり,さらにその内 75\%以上は 3-DGであった。このことから, 中性透析液の低 GDPs 化には 3-DG と 5-HMFを低隇させることが重要で ある。しかし，3-DG と 5-HMF はグルコース室側 $\mathrm{pH} 4.5$ 付近で鏡像的変化をするため, $\mathrm{pH}$ による調整 は困難である。3-DG と 5-HMF の toxicity について は不明であり，中性透析液によっては GDPsによる影 響に差がでてくることが示唆された．今後, 非加熱滅 菌による無 GDPs 化が必要である.

\section{文献}

1) Duwe AK, Vas SI, Weatherhead JW : Effects of the composition of peritoneal dialysis fluid on chemiluminescence, phagocytosis, and bactericidal activity in vitro. Infect Immun $33: 130-135,1981$

2) Yamamoto T, Sakakura T, Yamakawa M, Horiuchi N, Hirata S, Iritani Y, Nishitani H, Kim M, Kishimoto T, Chiku T, Matsumoto T, Horio T: Clinical effects of long-term use of neutralized dialysate for continuous ambulatory peritoneal dialysis. Nephron 60:324-329, 1992

3) Van Bronswijk H, Verbrugh HA, Bos HJ, Heezius ECJM, Oe PL, Van der Meulen J, Verhoef J : Cytotoxic effects of commercial continuous ambulatory peritoneal dialysis (CAPD) fluids and of bacterial exoproducts on human mesothelial cells in vitro. Perit Dial Int $9: 197-202,1989$

4) Wieslander AP, Nordin MK, Kjellstrand PTT, Boberg UC: Toxicity of peritoneal dialysis fluids on cultured fibroblasts, L-929. Kidney Int $40: 77-79$, 1991

5) Martinson E, Wieslander A, Kjellstrand P, Boberg $U$ : Toxicity of heat sterilized peritoneal dialysis fluids is derived from degradation of glucose. ASAIO Journal 38:M 370-M 372, 1992

6) Nilsson-Thorell $\mathrm{CB}$, Muscalu $\mathrm{N}$, Andrén AHG, Kjellstrand PTT, Wieslander AP : Heat sterilization of fluids for peritoneal dialysis gives rise to aldehydes. Perit Dial Int 13 : 208-213, 1993

7) Wieslander AP, Deppisch R, Svensson E, Forsbäck G, Speidel R, Rippe B : In vitro biocompatibility of a heat-sterilized, low-toxic, and less acidic fluid for peritoneal dialysis. Perit Dial Int 15:158-164, 1995

8) Wieslander $A$, Lindén $T$ : Glucose degradation and cytotoxicity in PD fluids. Perit Dial Int 16 (Suppl 1) : S 114-8, 1996

9) Anet EFLJ : 3-Deoxyglycosuloses (3-deoxyglycosones) and the degradation on carbohydrates. Adv Carbohydr Chem 19: 181-218, 1964

10) Feather MS, Harris JF : Dehydration reactions of carbohydrates. Adv Carbohydr Chem Biochem 28 : 161-237, 1973

11) Okada $S$, Iga $S$, Ueoka $S$, Isaka $H$ : Studies on physico-chemical examination of glucose injection. Bull Natl Inst Hyg Sci Japan $89: 87-90,1971$

12) Taylor RB, Jappy BM, Neil JM : Kinetics of dextrose degradation under autoclaving conditions. J Pharm Pharmac 23:121-129, 1971

13) Anet EFLJ : Degradation of carbohydrates. Aust J Chem 15: 503-509, 1962

14) Jellum E, B $\phi$ rresen HC, Eldjarn $L$ : The presence of furan derivatives in patients receiving fructosecontaining solutions intravenously. Clin Chim Acta $47: 191-201,1973$

15) Trzeciak M, Zakrzewski Z, Siedlecka E, Furmańczyk $Z$ : Studies on dependence of stability of glucose in solutions applied to peritoneal dialysis upon their electrolyte composition, Acta Polon Pharm 51: 174-178, 1989

16) Kjellstrand $\mathrm{P}$, Martinson $\mathrm{E}$, Wieslander $\mathrm{A}$, Holmquist $B$ : Development of toxic degradation products during heat sterilization of glucose-containing fluids for peritoneal dialysis : Influence of time and temperature. Perit Dial Int 15:26-32, 1995

17) Nakamura S, Miyazaki S, Sakai S, Morita T, Hirasawa $Y$, Niwa T : Localization of imidazolone in the peritoneum of CAPD patients : a factor for a loss of ultrafiltration. Am J Kidney Dis 38 (Suppl 1) : S 107-S 110, 2001

18) Kato H, Van Chuyen $N$, Shinoda T, Sekiya F, Hayase F: Metabolism of 3-deoxyglucosone, an intermediate compound in the Maillard reaction, administrated orally or intravenously to rats. Biochim Biophys Acta 1035 : 71-76, 1990

19) Kanazu $T$, Shinoda $M$, Nakayama $T$, Deyashiki $Y$, Hara A, Sawada $\mathrm{H}$ : Aldehyde reductase is a major protein associated with 3-deoxyglucosone reductase activity in rat, pig and human livers. Biochem $\mathrm{J}$ 279: 903-906, 1991

20) Sato $K$, Inazu A, Yamaguchi S, Nakayama $T$, Deyashiki Y, Sawada H, Hara A : Monkey 3-deoxyglucosone reductase: Tissue distribution and purification of three multiple forms of the kidney enzyme that are identical with dihydrodiol dehydrogenase, aldehyde reductase, and aldose reductase. Arch Biochem Biophys 307:286-294, 1993 
21) Ateshkadi A, Johnson CA, Founds HW, Zimmerman SW : Serum advanced glycosylation end-products in patients on hemodialysis and CAPD. Nephrol Dial Transplant $15:$ 129-133, 1995

22）ブドウ糖注射液. 第十四改正日本薬局方解説書, p C2433-C2435，廣川書店，東京，2001

23) Ulbricht RJ, Northup SJ, Thomas JA : A review of 5-hydroxymethylfurfural (HMF) in parenteral solutions. Fundam Appl Toxicol 4:843-853, 1984

24) Wieslander AP, Andrén AHG, Nilsson-Thorell C, Muscalu N, Kjellstrand PTT, Rippe B : Are aldehydes in heat-sterilized peritoneal dialysis fluids toxic in vitro? Perit Dial Int $15: 348-352,1995$

25) Witowski J, Korybalska K, Wisniewska J, Breborowicz A, Gahl GM, Frei U, Passlick-Deetjen J, Jörres A : Effects of glucose degradation products on human peritoneal mesothelial cell function. J Am Soc Nephrol 11:729-739, 2000

26) Taher AM, Cates DM : A spectrophotometric investigation of the yellow color that accompanies the formation of furan derivatives in degraded-sugar solutions. Carbohydr Res 34 :249-261, 1974

27) Kato F, Mizukoshi S, Aoyama Y, Matsuoka H, Tanaka $H$, Nakamura $\mathrm{K}$, Tsukamoto $\mathrm{M}: \mathrm{Im}$ munosuppressive effects of 3,4-Dideoxyglucosone$3-$ ene, an intermediate in the Maillard reaction. J Agric Food Chem 42 : 2068-2073, 1994

28) Linden $T$, Cohen $A$, Deppisch $R$, Kjellstrand $P$, Wieslander A:3,4-Dideoxyglucosone-3-ene (3,4DGE) : A cytotoxic glucose degradation product in fluids for peritoneal dialysis. Kidney Int $62: 697-$ 703, 2002

29) Ledebo I, Wieslander A, Kjellstrand P : Can we prevent the degradation of glucose in peritoneal dialysis solutions ? Perit Dial Int 20 (Suppl 2) : S 48S 51, 2000

30) Witowski J, Wisniewska J, Korybalska K, Bender TO, Breborowicz A, Gahl GM, Frei U, PasslickDeetjen J, Jörres A : Prolonged exposure to glucose degradation products impairs viability and function of human peritoneal mesothelial cells. J Am Soc Nephrol 12:2434-2441, 2001 